\title{
Tourism Crisis and Safety Management
}

\author{
David Beirman
}

\begin{abstract}
Safety and security have emerged as key issues in the global tourism industry at the destination dimension, the sectoral dimension and for individual tourism businesses. The prevalence of crime, terrorism, cyber security threats, medical and physical risks arising from human activity and natural phenomena are influential factors in the choices tourists make for destinations and products-choices. Safety is now widely regarded as the key determinant in consumer choices of destinations and tourism products including accommodation, airlines, land and sea transport brands, attractions or the decision to participate in or attend events.

Brazil's hosting of the 2016 Olympic Games in Rio de Janeiro was subject to extensive and often negative coverage media related to crisis and safety management. The two key issues of concern for visiting international athletes and their supporters were Brazil's high crime rate and the risk of contracting the Zika virus. Since the turn of the $21^{\text {st }}$ century, tourism safety has evolved from being a management imperative for specific sectors of the tourism industry to an holistic management issue for destinations and all sectors of the tourism industry.(Pizam \& Mansfeld 2006, Tarlow 2014).

This chapter examines the key theoretical developments in the growing field of tourism crisis and safety management. It highlights the fact that since the $9 / 11$ terrorist attack of 2001, tourism crisis management and security has emerged from being a marginal issue to a core field of research for tourism academics and a core management concern of tourism industry practitioners across all sectors of the tourism and hospitality industry.

There are three key issues discussed in this chapter which dominate the field of tourism crisis and safety management today and are expected to do so for the foreseeable future. The first involves the linkage between the breakdown of safety and security and its descent into a business, sectoral or destination crisis. The second issue is the management of safety, security, crisis and recovery in a tourism context from the proactive or contingency dimension. The third issue, a priority of the UN World Tourism Organisation since 2010, involves the integration between tourism and emergency management in preparing for and responding to crises related to safety and security challenges.
\end{abstract}

\section{Bio}

David Beirman is a senior lecturer in Tourism with the Management Discipline Group, UTS Business School, University of Technology-Sydney. Prior to joining UTS as a full-time lecturer in 2009 he had 30 years of hands-on experience in the Australian travel industry as a travel agent, tour wholesaler and in destination marketing and management. He retains close working relations with the Pacific Asia Travel Association. 


\section{Keywords}

\section{Tourism Safety Management, Tourism crises, integration tourism and emergency}

management

\section{Introduction}

There is a significant linkage between tourism safety and tourism crises. A review of recent destination tourism crises, reveal that many tourism related crises are a direct consequence of safety and security breaches and shortcomings. Terrorism is a global phenomenon which involves multiple targets. BetweenPuring 2015 and 20176, terrorist attacks targeting tourists and tourism infrastructure have occurred in countries as diverse as Tunisia, Belgium, Burkina Faso, France, Germany, the United Kingdom, Spain, Philippines, Egypt, Thailand and Turkey. These incidents either primarily or exclusively targeted tourists. Terrorism continues to be a serious safety issue for tourism. However, the direct targeting of tourists by either terrorists or criminals is not in itself, a requisite for negative perceptions of tourist safety. Tourism security and safety and by implication the reputation of a tourism destination, can be threatened by natural disasters, pandemics, political insecurity, bushfires, a high crime rate or even poor governance of buildings, food and water, transport systems and other infrastructure which renders them unsafe.

An attack on a group of tourists in January 2016 in Istanbul Turkey killed 11 German tourists and the June 2016 suicide bombing attack against Ataturk International Airport in Istanbul are just two of many recent examples of terrorists targeting tourists in Turkey. In both instances the attacks were followed by a significant decline in the number of international tourism arrivals to Turkey. The linkage between safety and crisis in Turkey is especially compelling. International tourism arrivals to Turkey from 2000-2014 were characterised by virtually uninterrupted growth from 8 million arrivals in 2000 to 41.26 million arrivals in 2014 which placed Turkey as a global top ten tourism destination in terms of visitor numbers and revenue. However, since 2015, Turkey growing exposure to terrorism coupled with pervasive political instability has led to a significant decline in tourism arrivals during 2015 and 2016. According to Trading Economics (2016), International tourist arrivals to Turkey in the period January-May 2016 are a disturbing $34.7 \%$ below the corresponding period in 2015. A decline of tourism arrivals on this scale constitutes a tourism crisis. The definition of a tourism crisis, based on the work of Faulkner (Ritchie 2009) and adapted by the author is "an event or a set of circumstances which severely compromises the marketability and reputation of a tourism destination or tourism business". This definition certainly applies to the impact of the recent spate of terrorist attacks in Turkey on the country's tourism industry.

This chapter analyses the issue of safety management in tourism from the perspective of the tourism security chain. The chain involves key security and safety issues which apply to specific elements (links) of the tourism operational and service chain. It is clear that each sector of the tourism industry has specific challenges and vulnerabilities. This chapter also identifies the link between a breakdown in the tourism security chain and tourism crises which impact on a destination.

The conceptual approach to linkage between crisis and safety management is illustrated by references to destinations and tourism businesses in which safety issues have precipitated a crisis. In reference to safety and security management this chapter focuses on two key approaches to safety and security management in tourism. Firstly, on proactive, risk management or contingency policy measures designed to minimise the exposure of tourists and tourism infrastructure to safety and security threats and secondly on reactive approaches 
which will examine how destination, industry sectors and tourism businesses manage their operational and reputational recovery safety/security in response to a crisis.

\section{Contextualising Safety and Crisis Management}

In order to contextualise issues discussed in this chapter it is critical to establish the core safety threats which are addressed. The concept of tourist safety involves a feeling of both physical and psychological security when individuals or groups visit a place outside their usual environment (Moreira 2013, Pizam \& Mansfeld 2006)). It is natural for most tourists to experience a sense of anomie or vulnerability when visiting an unfamiliar destination. Arriving at a destination in which language, cultural, climatic, physical and security environments are unfamiliar, engenders feelings of uncertainty and insecurity. Many tourists who pre-plan their travel arrangements within the industrialised tourism system can mitigate this vulnerability or safety risk by booking stopover packages at the point of arrival or longer tour packages. Most gateway packages include meet and greet at the point of arrival, transfers between the airport/seaport/rail or bus terminus and their first night/s accommodation and even brief familiarisation tours at the destination. Although there are many dimensions of safety which impact on the tourism experience this chapter will focus on a range of specific safety issues:

- Physical safety and exposure to violent attacks occasioning murder, bodily harm or sexual violation.

- Threats to physical safety arising from crime, terrorism, political, racial, ethnic and religiously motivated violence.

- Threats to property or valuables through robbery, fraud, scams, overcharging of services, cybercrime directed at credit or debit card accounts.

- Threats to psychological well-being arising from threatening behaviour or engendering a hostile social environment directed at tourist.

- Threats to physical security arising from natural disasters and extreme climatic events.

- Threats to physical security arising from product failure, fire, mechanical failure, construction failure.

- Threats to physical security arising from management negligence or failure to observe due diligence with occupational health and safety procedures.

- Threats to health and physical wellbeing arising from poor health services, exposure to epidemics and pandemics and poor governance of food and water standards.

It is readily conceded that threats to tourist safety extend beyond those identified above. However, in the space of one chapter the above issues represent a significant range of threats.

\section{Figure 1. The Tourism Security Cycle (Beirman and Van Walbeek 2011)}

Figure 1 illustrates that the various links of the tourism service and experience chain are subject to variable safety threats and therefore require specific approaches to safety management. Since the 9/11 attack of September 2001 the airline and airport sectors through 
the offices of the International Air Transport Association (IATA) the International Civil Aviation Organisation (ICAO) and Airports Council International (ACI) made significant changes to safety protocols which applied universally to airlines and airports (Page 2009). The main reason that safety protocols in the aviation and airport sectors can be applied globally is that aviation's global governance organisation, the ICAO, is a UN body with global legitimacy and authority to globally enforce rules, regulations and standards within the airline sector. Passengers using airports and airlines have largely accepted a rigid safety and security culture which involves extensive body and baggage screening. However, even in the airport environment there is a significant distinction between the non- invasive security strictures which apply to the land side and the relatively invasive security measures which apply to the air side sections of the world's airports. In common with the aviation sector, global cruising also features a high level of global standardisation of safety protocols. In the case of cruising, these are set by the International Maritime Organisation, (IMO which is a UN body). These protocols are supported by the global cruise industry association, Cruise Lines International Association (CLIA) which requires adherence to the IMO's Safety of Life at Sea (SOLAS) protocols established in 1974 and updated in 2010 which set minimum global standards for the safe operation of cruise ships (IMO 2016).

One of the greatest safety and reputational challenges faced by the transportation sector is the impact of product failure resulting in airline crashes/ disappearances, breakdown or sinking of ships, rail derailments, coach or motor vehicle crashes. Prior to 2014, Malaysian Airlines had established a strong reputation as one of the safest airlines in Asia. However two incidents which cost over 400 lives, namely the still unsolved disappearance of MH 370 in March 2014 and the shooting down of MH 17 over the Ukraine in July of that year transformed the perception of Malaysian Airlines from one of a well- regarded international carrier to that of a high risk carrier. While perceptions of this sort are often erroneous and unfair, perception play a powerful role in determining the nature of crisis in tourism. As cruise ships, aircraft, trains and buses expand in size to accommodate larger numbers of passengers the ultimate safety risk is that in the unlikely event of them experiencing mechanical failure or crashing or sinking, the potential consequences in terms of human lives are massive. The world's largest cruise ship, Ovation on the Seas accommodates over 6,000 passengers and 2,500 crew members. As the 2012 sinking of the Costa Concordia in Italy demonstrated, the combination of a good ship and an inattentive captain can potentially be disastrous.

In contrast to the high level of centralised global safety standards which apply to aviation and cruising, globalised safety standards and protocols don't apply to the accommodation sector. There is no UN body or global association imposing global governance on safety standards on the accommodation sector. The global industry body which claims to represent the hospitality sector, the International Hotel and Restaurants Association, (IH\&RA 2016) is more actively engaged as a networking and occasional advocacy body than as an association which sets operational, managerial or governance standards. In the accommodation sector, safety and security standards are aligned with national and state laws which apply to duty of care and occupational health and safety laws which apply to the legal jurisdiction in which the accommodation operates.

Despite the absence of global governance, many multinational accommodation chains do set strict standards and protocols for safety and security which apply to properties and brands owned or franchised by the chains. Chains such Accor and the Intercontinental Hotel Group promote their commitment to safety as a marketing and reputational advantage. However, the rise of the shared economy and the phenomenon of Air B n B have resulted in safety standards for these properties being a secondary consideration. At a broader level, the accommodation and hospitality sector faces the considerable challenge of balancing the 
expectation of being hospitable and welcoming to all comers while concurrently providing security and safety for their paying guests (Cronin and Parry 2015). Unlike the airline and airport environment, accommodation providers and many of their guests have found it difficult to accept or practice the screening strictures which commonly apply to consumers in the transport sector. Since the post $9 / 11$ security upgrades to airlines and airports, the majority of serious crime and terrorism incidents targeting tourists have occurred in hotels, resorts and restaurants as they are considered softer targets than airlines and airports. Wholesale tour operators which package complementary tourism component from multiple sectors tend to exercise a strong commitment to duty of care and generally take responsibility for the safety of their clients and the management of their clients affected by a crisis event. Both the National Tour Association, the peak body of US based tour operators (Tarlow 2014) and the Council of Australian Tour Operators, the peak body of Australian based outbound tour operators have established a common set of guidelines for the safety and crisis management for clients participating in their programs around the world (Beirman 2016). As these introductory remarks attest, any discussion of safety and security risks applying to tourism should take into account the specific sectoral issues which apply. However, from a destination management perspective, safety and security threats, irrespective of which sector of the tourism industry is affected does impact on the perception of a destination's safety. Research conducted by Tourism Research Australia (2016) and the work of Ritchie and Crouch (2003) indicate that safety is the most important determinant of a traveller's decision to choose a destination. In 2016 alone, terrorist attacks and security concerns in Istanbul, Nice, Orlando Florida, Brussels, Hua Hin (Thailand) and Rio de Janeiro all had negative impacts on the safety perception and ensuing tourist flows to the destinations. However tourism safety extends far beyond exposure to terrorism and crime. Natural disasters in the form of volcanoes, earthquakes, storms, sea surges, tsunamis have significant impact on tourism safety, especially in those parts of the world which are vulnerable to natural disasters. In recent years, pandemic outbreaks of SARS (2003), H1N1 "Swine Flu" 2009, Ebola in West Africa (2014) and the Zika Virus in 2015-6 which is now prevalent in over 50 countries can be legitimately considered as safety concern for tourists. Significant transnational health threats need to be factored into the range of safety threats to tourism.

In 2011 The UN World Tourism Organisation sought to add a new dimension to the management of destination orientated tourism safety and crisis management. The author, in association with Dr Dirk Glaesser, then head of the UNWTO's risk and crisis management unit and the Australian Emergency Management Institute organised the first of two conferences held in Australia in 2011 and 2012 which mapped out a strategy for integrating emergency management and tourism (Beirman 2011, Glaesser 2011). This approach involved a holistic view of linking the safety procedures of tourism businesses and infrastructure with emergency management agencies and first responders including police, civil defence and rescue agencies, ambulance, fire fighters and surf lifesavers. This concept also explored enhancement to the safety dimension of tourism infrastructure to minimise exposure to natural disasters. In Japan, after the 2011 earthquake/tsunami the Prefecture of Okinawa chose to site coastal resorts on ground that would be above the inundation level of the most severe recorded tsunami (Takamatsu 2014) which occurred in 1768. Prior to the UNWTO initiative there had been some specific programs of integration between emergency management and tourism.

Airports have integrated airline operations at airpertson site with emergency management for many years. In the Americas, Dr Peter Tarlow has worked closely with police forces in North America and South America for over 20 years to develop a programme called Tourism Orientated Policing and Protection Services (TOPPS) which sensitises police services to address policing to various vulnerabilities of tourists who visit their cities and towns (Tarlow 
2014). Tarlow's fluency in English, Spanish and Portuguese has enabled him to disseminate and present the program in every North and South American country. Although police are charged with the protection of all permanent and temporary inhabitants on their "beat" the presence of tourism, coupled with attractions and events which draw tourists, creates a range of challenges. In many countries where are there are identifiable concentrations of tourists especially designated tourism police (many of whom are multilingual) have been employed by local authorities to undertake both a law enforcement and informational role in their beat National, state/provincial/ prefectural, global and transnational tourism associations have all paid increasing attention to safety and crisis management in recent years. The UNWTO commissioned its crisis management toolkit in 2011. It also developed its on-line crisis management program Tourism Emergency Response Network (TERN). The Pacific Asia Travel Association established its first crisis management taskforce in 2003 following the October 2002 Bali bombing. In 2003 and 2011 PATA commissioned risk, crisis and recovery guide books and training programs for its members. This author was the co-author of the PATA's 2011 Bounce Back guide (Beirman and Van Walbeek 2011) which was supported by a series of webinars held in 2012 and 2013. In 2012 The World Travel and Tourism Council ran its global tourism summit in Japan as a mark of support for Japan's recovery from the 2011 tsunami. The theme of the summit was safety and resilience. At the sectoral level (with the notable exception of the accommodation sector) and the destination dimension global and transnational tourism associations now recognise that safety and crisis management is a field which requires integration into the management of tourism.

Governments take tourism safety and security and crisis management seriously for outbound tourists through government travel advisories and crisis units which generally operate under the auspices of foreign ministries (Beirman 2006, Roach and Kemish 2006). They also exercise a growing level of policy control over crisis management in the tourism for inbound/ incoming tourism. Some of the policy settings for safety and crisis management operate on a national basis. This is the case in Australia (Emery 2012) and some operate on a transnational basis as they do in the ASEAN region and the Caribbean region (ASEAN Tourism 2015).

Many countries, especially those which have a high level of economic dependence on tourism recognise that negative safety perceptions and poor crisis management hasve the potential to cause reputational damage to the country as a tourist destination. Reputational damage brings with it serious economic and employment consequences (Granville, Mehtra, Pike 2016). The private sector is playing an increasingly important role in both safety and crisis management in tourism and events. Until 2002 IATA had its own crisis communications management unit but in that year this unit and its role was outsourced to Kenyon which is one of the world's largest multinational security and emergency management companies (Edwards 2012). International SOS, is one of the world's largest specialist tourism safety and crisis management companies employing over 14,000 people and operating in over 50 countries (International SOS 2016). Much of its work supports corporate duty of care as it applies to business travellers and it assists companies in determining corporate travel safety policies and providing support for its clients when they find themselves in a crisis situation. It also provides an independent safety and security assessment of global destinations. The above companies and many smaller companies offer risk, security and crisis management services which focus on specific sectors of the tourism and events industries. Within some of the larger tourism, attractions and event industry companies there are specific divisions within the companies responsible for safety and crisis management. This is certainly prevalent among the larger hotel chains, individual airlines and multi branded attractions such as Merlin Entertainments (2016) and the Disney group. The insurance industry and especially travel insurance providers play a critical role in security and crisis management for both business and leisure travellers. A key message issued by most 
governments in their travel advisories is the exhortation to leisure and business travellers to purchase appropriate travel insurance coverage when travelling internationally.

A holistic context of safety and crisis management for all sectors of business, including tourism, has been set by the International Standards Organisation. Most researchers, students and practitioners of risk management are familiar with ISO 31000 -2009 ( Standards Australia 2009) which is the latest iteration of the ISO on risk management. The following model sets the framework for risk, safety and crisis management which is now widely employed throughout the global tourism and hospitality industry. It forms the basis for legal frameworks which apply to safety and duty of care which apply to tourism globally.

Figure 2. ISO 31000-2009 International Standards Association Risk Management Matrix (source International Standards Organisation)

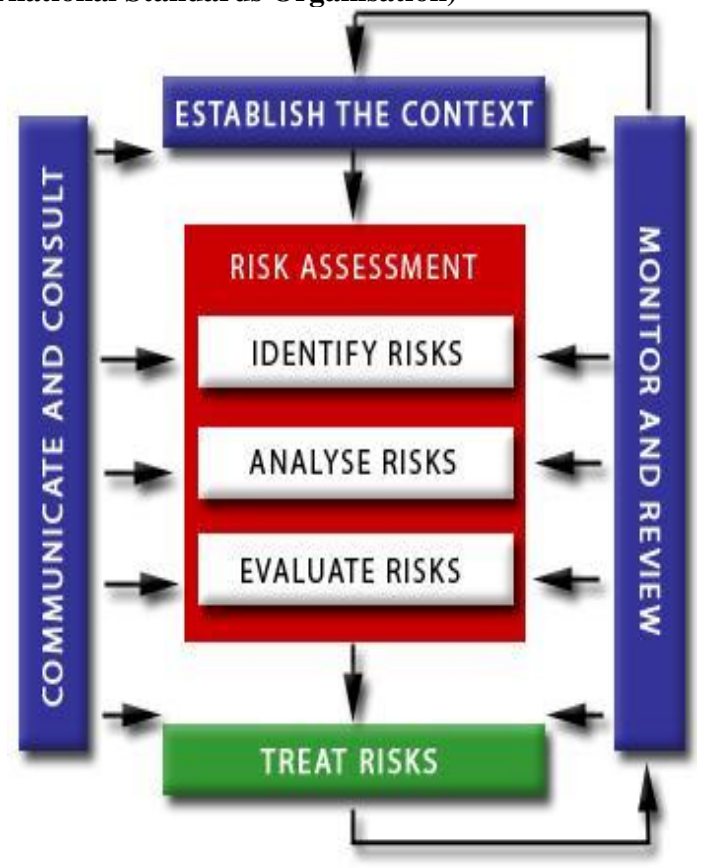

The ISO risk management matrix generally applies to the development of proactive risk management policy and practice. The prevailing trend within the tourism and events industry is for the public and private sector of tourism and events to adopt a proactive approach to safety and crisis management. This is partially due to the fact that with the growing prevalence of social media and instant global news, a delayed reaction to a negative event can rapidly escalate at situation from a mishap to a crisis without a high level of preparedness and a facility to engage in crisis communications from the onset of a negative event.

\section{Literature Review}

Brent Ritchie has provided some of the most comprehensive theoretical coverage of crisis management literature. In his book, Crisis and Disaster Management for Tourism (Ritchie 2009) he undertakes a comparative analysis of the crisis and disaster lifecycle as developed by Faulkner (2001), Fink (1986) and Roberts (1994).

Essentially the lifecycle of a tourism related crisis occurs in six distinct stages. 
1. The Pre-event stage in which a tourism destination or business has focused on a range of proactive or risk management measures to ensure they are prepared for the situation which are deemed to be most likely threats. In the risk management context this planning for those events or situations which have a high level of likelihood and the most serious consequences. In the context of security this would mean preparing for the most likely security threats to a business or a destination.

2. The prodromal stage in which a crisis event is likely to occur. In relation to natural disasters, especially weather related events such as hurricanes and floods, there is frequently an onset period which enables tourism businesses and destinations an opportunity to make some urgent defensive preparations. However, there are many security related situations in which there is either no or minimal prodromal phase. Terrorist attacks, earthquakes, plane crashes often occur without warning.

3. The emergency phase is the point at which the crisis event is in train and core focus is on rescue, relief and damage minimisation. A key priority involves ensuring stakeholders are made aware of the situation.

4. The intermediate phase in which the tourism destination and business assess the impact of the crisis and begin the process and develop a timetable of recovery and rehabilitation.

5. Long term recovery which involves rebuilding the reputation of the business and destination. In crisis management parlance this involves sensing the opportunity which has arisen from the danger.

6. Resolution which in many cases involves learning from errors in action and policy and restoring the business or the destination to a higher level of resilience. To use the words of Sandy Holway (Beirman 2016) "build back better".

From a safety and security perspective emphasis need to be placed in the early stages of the crisis lifecycle. Takamatsu's work in Okinawa (Takamatsu 2014) took place in Okinawa following Japan's massive March 2011 Tohoku earthquake and tsunami which struck NSE Honshu. His company, Japan Marketing Co. was commissioned by the prefectural government of Okinawa to develop a risk and crisis management strategy to minimise the threat to people and tourism infrastructure of a major natural disaster. Central to his strategy was researching the records of historical tsunamis and identifying the most severe in recorded history. His strategy essentially was designed to cope with the 1768 worst case tsunami in Okinawa's history. Japan's vulnerability to volcanoes, earthquakes and tsunamis have resulted in a culture is highly attuned to the importance risk management and preparedness. This has been reflected in the building regulations which apply in Okinawa to newly constructed resorts which requires all accommodation to be sited at least 35 metres above sea level. Risk management approaches are especially relevant when preparing to deal with security related threats.

Heath's 4 R model for crisis planning and management (Heath 1998) is well received by tourism industry practitioners. The $4 \mathrm{R}$ 's are easily committed to memory and in essence it incorporates the key elements of Faulkner's model. It forms the basis of the crisis management approach employed by the key transnational tourism industry associations including Pacific Asia Travel Association, ASEAN tourism and the UN World Tourism Organisation,

Figure 3. Heath's 4 R Model for Crisis Planning and Management as depicted by the Pacific Asia Travel Association 


\begin{tabular}{|c||c|c|}
\hline \multirow{2}{*}{1} & 1.1 & Crisis Awareness \\
\cline { 2 - 3 } & 1.2 & Political awareness \\
\cline { 2 - 3 } & 1.3 & Standard Operating Procedures \\
\hline \multirow{3}{*}{ 2. Readuction } & 2.1 & Crisis Management Plan \\
\cline { 2 - 3 } & 2.2 & Tourism planning \\
\cline { 2 - 3 } & 2.3 & Health and safety measures \\
\hline \multirow{3}{*}{ 3. Response } & 3.1 & Emergency response procedures \\
\cline { 2 - 3 } & 3.2 & Investigation \\
\cline { 2 - 3 } & 3.3 & Family assistance \\
\cline { 2 - 3 } & 3.4 & Communication \\
\hline & \multicolumn{3}{|c}{} \\
\hline \multirow{4}{*}{ 4. Recovery } & 4.1 & Business Continuity Plan \\
\cline { 2 - 3 } & 4.2 & Human Resources \\
\cline { 2 - 3 } & 4.3 & Debriefing \\
\hline
\end{tabular}

In Figure 3, the Reduction phase of Heath's model is dominated by the risk management roles of developing standard operating procedures and the prioritisation of risk likelihood and consequence. In mega events in which tourism and the event itself are closely interrelated, the development of effective security measure and planning become vital. Mega events such as the Olympic Games or the World Cup football tournament present an acid test to tourism and event planners. A successful and secure event can greatly enhance the reputation and marketability of the host destination. Conversely, security problems can damage the reputation of a destination. In the lead up to Brazils hosting of the 2014 World Cup and the 2016 Olympic Games in Rio de Janeiro there was a considerable amount of negative coverage of Brazil's high crime rate. In fact tourists were the targets of opportunistic crime before and during both events.

The readiness phase in the Heath model also focuses on developing a set of contingency plans to deal with a crisis when it occurred. This involves establishing a crisis management team, developing a range of protocols for security, crisis communication and prioritising stakeholders. For tourism destinations and tourism businesses readiness for crisis management involves the development of a rapid response plan to communicate with both social and traditional media players (Pike 2008, Avraham and Ketter 2008).

The effectiveness of the response and recovery elements of the Heath model are highly dependent on the quality of the reduction and readiness elements. The Pacific Asia Travel Association established the PATA Rapid Response Taskforce in 2011. One of the key roles of the PRRT was to run a series of webinars pitched primarily at destination management organisations which trained DMO managers to manage crisis in accordance with the Heath model. There was a broad acceptance that for most destinations, a crisis of some sort was inevitable. The most pervasive economic and reputational concern shared by most DMOs share, is the ability to rapidly recover from a crisis situation. The core element of the PRRT's training was to inculcate a culture of crisis readiness among DMO's and tourism businesses. A variation of the Heath model is the Mitroff and Aganos (2001) best practice model in crisis management model (Ritchie and Crouch 2003. 


\section{Figure 4. The components of a best practice for crisis management (Adapted from Mitroff and Anaganos 2001)}

The above model factors a range of crisis scenarios which can vary according to severity and type. If we focus on the safety related crises this could incorporate crime, terrorism, pandemics, political instability, natural disaster or health threats. The systems involve crisis management protocols, security measures to protect tourists, tourism attractions and infrastructure. The mechanisms involve the ability to predict and detect the signals which could lead to a crisis. In common with other crisis management models preparation and contingency planning are the key determinants of effective and timely crisis response. A very specific tourism safety and crisis prevention method has been developed by US crisis management specialist, Dr Peter Tarlow. In close cooperation with various state and federal police agencies in the United States, he developed the concept of Tourism Orientated Policing/Protection Services following the 9/11 attack of September 2001 (Tarlow 2014). TOPPS is founded on recognition that the protection required for visitors involves some key differences to other forms of policing. This recognition was embraced both the US Homeland Security and by a number of state and county police forces in the US, notably, Las Vegas, the most tourism dependent city in the USA. As he points out, most visitors to a destination with which they are unfamiliar are naïve about the safety threat environment in which they are temporarily located. Tourists, lacking familiar social support groups are frequently more anxious and vulnerable than locals. Their lack of local language skills and knowledge of local customs adds to their vulnerability. Tourists are often aware about the nature of conducting relations with local law enforcement authorities. TOPPs is intended to sensitise law enforcement and security professionals to these issues.

In addition to protecting the tourists, TOPPS involves a focus on the protection of tourism infrastructure including hotels, resorts, transport termini and places within a destination which are frequented by tourists. The enhancement of security for tourists and the places they frequent is designed to be closely aligned to the reputation of the destination itself. TOPPs training has been provided to police forces, security professionals employed by tourist attractions, tourism, hospitality and events businesses and destination management organisations. Tarlow's fluency in Spanish and Portuguese has enabled him to apply TOPPS training to Latin America. He played an important role in training the Brazilian security organisations to apply the principles and techniques TOPPS to the policing of the 2014 World Cup in Brazil and more recently the 2016 Rio de Janeiro Olympics Games.

Although TOPPS has played an important role in sensitising law enforcement professionals and providing a systematic training program of policing for tourists in the America's, the concept of policing for tourists is not unique to the Americas. Many countries which have a high level of economic dependency on tourism have established Tourist Police units in counties as diverse as Thailand, Greece, Morocco and Egypt. Some of these units have been active for decades. A characteristic of most tourism police (Tarlow 2014) units is that they have a dual role of providing tourist with local information in addition to their law enforcement role. Many tourism police in the world are multilingual although this is should not be assumed that tourist police force members have fluency in languages other than their own.

Tourism policing, in common with most modern security techniques involves a combination of visible deterrence (uniformed security personnel) prominent signage or overt surveillance with covert and electronic security (plain clothed security personnel and concealed surveillance and screening equipment). Destination management and marketing organisations are increasingly incorporating safety messages to visitors in their marketing. In 2013 this 
author was involved in a conference in Thailand which canvassed the issue of providing safety do's and don'ts to intending international visitors (Beirman 2013). Government travel advisories issued by the foreign ministries of tourism generating countries have traditionally included this information in their advisories as integral to their duty of care protect their citizens travelling abroad.

The debate which occurred in Thailand focussed on whether Thailand would lose "face" by publicising that threats to safety exist at all or whether it would gain "face" by

acknowledging such threat and informing visitors of measures they could take to reduce their vulnerability to crime and scams. While Thai tourism professionals and officials at the Thai Tourism Authority are generally in favour of proactive safety warnings to inbound tourists, successive Thai government has been reluctant to support the concept based on the fear of "loss of face" though the admission of potential safety threats to visitors in Thailand. Such concerns are not unique to Thailand or for that matter to Asian countries. One of the difficulties that Egypt encountered following the initial "Arab Spring" uprisings in 2011 was a reluctance on the part of the Egyptian Tourism Authority to refer to any security problems in promoting a recovery of tourism despite the fact that such security issues were manifestly obvious. From a destination management perspective, a growing number of national destinations have supported proactive warnings to tourists usually couched in positive language. The author was involved with UK based Tourism Crisis management specialist Dr David Pearl in developing such a program for Trinidad and Tobago in 2006, at a time when Trinidad and Tobago had the misfortune to be declared as crime capital of the world. (The Trinidad and Tobago Guardian May 11, 2016) The Trinidad \&Tobago Ministry of Tourism and the government chose to deal with this significant reputational challenge by upgrading tourism security throughout the country and educating tourists to minimise their exposure to security threats by publicising a range of safety do's and don'ts for visitors to the country. This followed the model the South Africa Tourism Board on proactive security advice for tourists which they successfully introduced in 1999 in response to a crime problem in that country (Beirman 2003).

Since 2010 the UNWTO has advocated a move towards the integration of tourism and emergency management. In 2010 the UNWTO's Risk and Crisis Management Unit under the leadership of Dr Dirk Glaesser, canvassed a global approach to enhanced integration between the tourism industry and emergency management agencies (Glaesser 2011). This led to two conferences both held in Australia respectively in 2011 and 2012 which focussed on the applying the concept of integration to the management of tourism risk, security and crisis. The conferences were jointly run by the UNWTO, the Australian Institute of Emergency Management and the author. They attracted leaders from the emergency management sector, the tourism industry leadership and government officials from over ten countries. The safety of tourism infrastructure and tourists rely on the full gamut of emergency management providers from first responders to those responsible for safety governance. These include police, ambulance, first aid and rescue services, doctors, nurses and hospital staff, fire fighters, surf lifesavers and officials responsible for enforcing building and health regulations.

The integrative model the author devised (Beirman 2011) was effectively a bilateral approach to security in which emergency services assisted tourist and tourism infrastructure while tourism infrastructure and tourism professionals could also provide services and support to emergency management agencies. To illustrate the concept, in the event of a natural disaster such as a cyclone/hurricane, evacuation and assembly arrangements would be jointly determined by a resort management and the local emergency services. Solidly constructed resorts could provide emergency accommodation and food for local residents and tourism guests. Boats owned by the resort could assist in emergency evacuations, flood mitigation 
work and rescue. The concept of integration, between emergency management especially in a crisis situation is essentially collaborative.

As Weaver and Lawton (2014) along with many other tourism scholars have pointed out, some of the world's most popular tourist destinations located in the "pleasure periphery". This means many tourist destinations are located in warm/tropical coastal regions which are frequently subject to storms, flooding and occasionally earthquakes, tsunamis and even forest fires. The integrative model proposes two alternative approaches to the integration of emergency management and tourism. The first is essentially a consultative path by which tourism industry bodies will consult with emergency management agencies to alert them to the specific needs of tourists and tourist infrastructure as it applies to the area of jurisdiction. The second and more integrative path would involve tourism organisation playing an integral role in emergency management planning and response.

A practical illustration of this integration in action was a document and training kit produced by Tourism Victoria in 2015 (Tourism Victoria 2015) which explains to all tourism stakeholders and to tourists themselves the preventative and response approaches which apply to bushfires in Victoria. Dr Stewart Toplis who is Tourism Victoria's head of risk management and the author of the manual adopted the key approaches to the integration of emergency management and tourism outlined by the UNWTO.

In 2012 the author was in Okinawa to witness the concept of integration in operation within the Japanese Prefecture of Okinawa. In the case of Okinawa, the impetus to practice integration was initiated from the Prefectural governor. The level of cooperation between the tourism industry and emergency management agencies in Okinawa in the years following the 2011 Tohoku -earthquake/tsunami reached a level which approached religious zeal. Although the 2011 tsumami had negligible impact on Okinawa (a two hour flight from Tokyo), all Japanese are deeply conscious of the country's vulnerability to meteorological, seismic and tectonic forces. In the case of Okinawa, there was a zealous determination to position Okinawa as the safest destination on earth. As it turned out the campaign was highly successful in stimulating significant tourism growth post 2011 from both international and domestic tourists.

The Okinawa example highlights the important political dimension associated with safety and crisis management in tourism. With tourism in 2016 representing a global financial contribution of US\$7 trillion to the global economy, direct employment of 250 million people worldwide and international tourism visitors exceeding 1.2 billion people (World Travel and Tourism Council 2016) the industry has now reached a stage where tourism is a strategically vital element in many national economies. As Avraham and Ketter (2016) point out, this is especially true of many developing countries. Consequently, reputational damage arising from security concerns or crisis events involving tourism can be especially harmful to those fragile economies in the developing world which have a high level of dependence on tourism. The final theoretical dimension to be explored in this chapter is the role of collaboration in tourism safety and crisis management. In discussing the issue of safety and crisis management in this chapter all the specific approaches discussed lead to the common destination of collaboration.

The tourism industry is a highly fragmented industry based largely on its division into discrete product and operational sectors of transport, attractions, accommodation, cruising, distribution, destinations and the additional fragmentation within those sectors (Jamal and Getz 1995, Selin 1994, Dwyer et al 2009). However, most marketable tourism products involve varying degrees of collaboration and cooperation between various businesses to provide an attractive buying proposition. The core principle of wholesaling involves the packaging of complementary transport, accommodation, attractions, tour guides, restaurants 
and sometimes events to market and sell an integrated tour product via traditional and on-line retailers to the consumer.

In the field of destination safety and crisis management collaboration is exceedingly important and at the destination dimension, most collaboration between the public and private sectors of tourism are coordinated by government owned and operated destination marketing/management organisations in association with government security and law enforcement agencies.

Dwyer's discussion on trends analysis (Dwyer et al 2009) focussed on the drivers of collaboration which result from political, economic, environmental, social and technological trend analysis. The years, 2001-2004 involved a series of events including 9/11 (2001), the Bali bombing (2002) and SARS (2003), Indian Ocean Tsunami (2004) which positioned safety, security and crisis management to the top of the tourism industry agenda.

Consequently the political impetus to enact measures to enhance tourism security coincided with the tourism industry's need to be seen as proactive on travel safety and crisis management.

Jamal and Stronza (2009) assert that collaboration is integral to planning domains which involve multiple stakeholders. A problem domain refers to a situation in which the problem of crisis and security management are complex and require an inter or multi-organisational response involving a broad coalition of stakeholders. The development of shared set of policy directions within a problem domain requires collaboration among multiple stakeholders who may hold diverse views and have varying degrees of influence over decision making. To clarify this point, destinations which host major events will usually develop common security approaches which may apply to tourism precincts, event venues, transport termini and accommodation which may be coordinated either by military or police authorities.

Since 2003 the author has been involved with the Australian Department of Foreign Affairs and Trade's Consular Consultative group. This group is a collaborative consultative group representing key Australian government departments and the leadership of all sectors of the Australian outbound tourism industry. The purpose of the group is to establish easily communicable travel advisories, safety advice and crisis management protocols applying to Australians who travel internationally. In this case, organisations as varied as IATA, PATA, key airlines, Cruise Lines International, The Australian Federation of Travel Agents, the Insurance Council of Australia, The Council of Australian Tour Operators, Lonely Planet, Expedia, Association of Corporate Travel Executives and Travel Doctors share a common commitment to advancing tourism safety for outbound travellers.

Similar levels of collaboration also apply to safety and crisis management for inbound tourism at local, state/provincial, national and transnational level. Both the UNWTO through its TERN (Tourism Emergency and Response Network) and PATA's Rapid Response Taskforce have sought to apply common approaches to safety and crisis management at a transnational level. Due to the prevailing links between safety and destination/national reputation government agencies have tended to drive and coordinate safety and crisis management policy and crisis response.

\section{Conclusions}

The reputation of tourism destinations, tourism sectors and individual tourism businesses are increasingly being determined by the perception and reality of safety. The stakes involved in achieving and maintaining a good reputation for being a safe destination, hotel, airline, event, tour operator or cruise operator are very high indeed. As referred to earlier in this chapter, terrorist attacks directed at tourists and tourism infrastructure in Turkey during 2016 has led to a precipitous decline in international tourism arrivals to Turkey. This has led to significant 
job losses in the tourism sector and it affects a Turkish economy which has a significant reliance on tourism income.

The Arab uprisings, civil wars and political instability which have afflicted Arab countries since 2011 including Egypt, Syria, Yemen, Tunisia and Libya has resulted in severe economic losses and reputational damager which may take years to recover. It is worth noting that in 2010 Syria attracted over nine million international visitors. In 2016, despite a controversial (some may say cynical) attempt to depict Syria's Mediterranean coast as a tourism paradise, Syria's tourism industry is a remnant of its former self.

The author, as a former Director of the Israel Government Tourist Office (Australasia \& SW Pacific) had direct experience of the impact of negative security perceptions which applied to Israel during the "Al Aqsa Intifada" from September 2000-March 2004. International tourism to Israel, between $2000-2001$ plummeted by $67 \%$ and over 70,000 Israeli travel professionals lost their jobs during that year. Israel's tourism numbers did not recover to their 2000 levels until 2008. Tourism to the Palestinian Territories experienced an even more dramatic downturns during the same period (Beirman 2009).

The link between safety threats and tourism crises whether the safety threats arise from terrorism, crime, natural disasters or disease is manifest. While there will usually be a segment of each destination's tourism market which demonstrates a high level resilience and commitment to a destination due to family ethnic, religious or business links, the stalwart or core market is usually a small proportion of the total tourism market for any given destination. Leisure travellers which still make up the bulk of the global tourism market regards safety as a key motivating factor for destination choice.

The significance of safety applies at all levels of the tourism business. While price may be a major motivator for airline choice, safety tends to override it. After $9 / 11$ the airline and airport sectors implemented as set of re-calibrated security measures globally because the 9/11 attacks called into question the safety involved in flying on commercial airlines. The security enhancement to airlines and airports did leave other sectors of the tourism industry more vulnerable to security threats particularly from terrorist groups and this was certainly the case with accommodation sector.

This chapter has sought to track the development of inter sectoral collaboration in both the management of tourism security and shared approaches to tourism crisis management. These collaborative approaches have been undertaken at local, national, transnational and global levels.

The UNWTO's push towards the integration of emergency management and tourism has involved a holistic all of government approach to tourism security. Transnational tourism associations including PATA and ASEAN Tourism have sought to inculcate a heightened awareness of the link between tourism security and tourism crisis. Most importantly there has been significant progress in the global industry's embrace of a proactive approach to tourism risk, safety and crisis management.

Although there has been significant progress in the field of tourism safety and crisis

management, since 2001, there remains a small minority of tourism destinations, sectors and tourism businesses who have not effectively addressed the issues. There are still destinations which labour under the delusion that if they don't address safety concerns then their prospective tourists won't notice. Some believe that if prices are discounted low enough for a tourism business or a destination which is deemed unsafe that tourists will take the risk. In the age of invasive and pervasive 24/7/365 news cycles and social media there are still some tourism businesses and destinations which believe they can transmit blatantly false messages and get away with it.

However, the majority of tourism businesses, sectors and destinations have accepted the link between safety and crisis management and are increasingly inclined towards inter-sectoral 
cooperation and collaborating with government to protect tourists, their businesses and the reputation of the destinations in which they operate.

\section{References:}

Avraham E., Ketter. E. (2016) Tourism Marketing for Developing Countries., Palgrave Macmillian, Basingstoke UK pp 1-33.

Avraham E. Ketter, E., (2008)Media Strategies for Marketing Places in Crisis. Elsevier Amsterdam. pp 11-87

Beirman D. (2011) The Integation of Emergency Management and Tourism. The Australian Journal of Emergency Management. Vol 36. No 3 July 2011 pp30-34

Beirman, D.,(2003) Restoring Tourism Destination in Crisis. Allen \& Unwin Sydney. pp 193-209

Beirman D., (2016). Tourism Risk, Crisis and Recovery Management Guide, Council of Australian Tour Operators. Sydney.

Beirman D, \& Van Walbeek B,(2011) Bounce Back.- Tourism Risk, Crisis and Recovery Management Guide. Pacific Asia Travel Association. Bangkok pp 10-22.

Beirman D. (2006) A Travel Industry Perspective on Government Travel Advsories. Chapter 21 Tourism in Turbulent Times. Eds Wilks, J, Pendergast, D. Leggat, P. Elesvier Amsterdam pp 309-319

Beirman D.(2013) Safety and Security in Tourism-How can Stakeholder be Involved by Turning Ideas into Action. Keynote Presentation, Thailand Tourism Marketing-Safety and Security Forum. Bangkok November 14, 2013. Organised by PATA, SKAL and the Thai Tourism Authority

Beirman D (2009), Crisis and Post Crisis Tourism Destination Recovery. Chapter 13. Eds Pforr, C., Hosie, P. Crisis Management in the Tourism Industry-Beating the Odds, Ashgate, Farnham. UK pp 207-224

Cronin, J. Parry, K., (2015) How Does Crisis Leadership Influence Effective Crisis Readiness? Chapter 5. Ritchie B., Campiranon, K., Eds., Tourism Crisis and Disaster Management in the Asia-Pacific., Cabi Publishing, Wallingford. Oxon. UK. pp. 6275.

Dwyer, L. Edwards, D. Mistilis. N, Roman. C, Scott. N. (2009)., Destination and Enterprise Management for a Tourism Future. Tourism Management (30)1, pp. 63-74

Edwards. M.(2012) The Role of the Private Sector in Emergency Management Response. Presentation by Mark Edwards Kenyon Vice President, Pacific region at UNWTO Integration of Emergency Management and Tourism Forum .Sydney Sep 2012.

Emery. W (2012)., National Tourism Incident Communication Plan. Australian Dept. of Resources, Energy and Tourism. Canberra

Glaesser, D. (2011) Towards a Safer World: The Travel and Tourism Sector, Presentation to UN World Tourism Organisation $1^{\text {st }}$ International Forum. Integration of Emergency Management and Tourism. Australian Emergency Management Institute. Mt Macedon Victoria, Australia September 2011.

Granville F. Mehtra. A, Pike S., (2016) Destinations, Disasters and Public Relations; Stakeholder Engagement in multi-phase Disaster Management., Journal of Hospitality and Tourism Management $\mathrm{Vol} 28$ (2016) pp 73-79

Heath. R., (1998)., Crisis Management for Managers and Executives. London: Financial Times Management.

International Hotel and Restaurant Association (2016) www.ih-ra.com Accessed 28/11/2016

International Maritime Organisation (2016) www.imo.org Accessed 28/11/2016

International SOS (2016) www.internationalsos.com accessed 28/11/2016 
Jamal, T., Getz D. (1995) Collaboration Theory and Community Tourism Planning, Annals of Tourism Research 22(1) 186-204

Jamal, T. and Stronza, A. (2009) Collaboration Theory and Tourism Practice in Protected Areas. Journal of Sustainable Tourism, 17(20, 169-189

Mansfeld Y., Pizam A., (2006) Towards a Theory of Tourism Security. Chapter 1. Mansfeld and Pizam eds. Tourism Security and Safety: From Theory to Practice. Elsevier. Amsterdam pp 1-23

Mitroff I., Anagnos G (2001) Managing Crises Before they Happen: What Every Executive Manager Needs to Know About Crisis Management. Amacon, New York.

Moreira P. (2013) Stealth Risks and Catastrophic Risks: On Risk Perception and Crisis Recovery Strategies.Chapter 2. Safety and Security in Tourism: Recovery Marketing After Crises. Eds. Scott N. Laws E. Prideaux, B. Routledge, Abingdon, Oxon, UK. pp $15-27$

Page, SJ., (2009) Transport and Tourism Global Perspectives. Pearson/Prentice Hall. Harlow UK pp 28-41

Pike, S.,(2008) Destination Marketing- An Integrated Marketing Communication Approach. Elsevier Amsterdam. pp 200-216

Pizam A, \& Mansfeld Y.(2006) Tourism Security and Safety. Elsevier. Amsterdam pp 1-27

Ritchie B W.(2009) Crisis and Disaster Management for Tourism. Channel View Publications. Bristol UK. pp 4-2

Ritchie JR, and Crouch G. (2003)., The Competitive Destination- A Sustainable Tourism Approach.,Cabi Publishing Wallingford UK. pp. 216-229

Roach, J., Kemish, I., (2006) Bali Bombings: A whole of Government Approach.Chapter 19. Tourism in Turbulent Times. Eds. Wilks, J. Pendergast, D. Leggat, P. Elsevier . Amsterdam. pp 277-290

Selin, S., (1994) Collaborative Alliances: New Interorganizational Forms of Tourism. Journal of Travel and Tourism Marketing, 2(2-3), 217-262

Standards Australia (2009)., AS/NZS ISO 31000:2009 Risk Management-Principles and Guidelines. Standards Australia. Sydney

Takamatsu M. (2014)., The Okinawa Tourism Crisis Management Initiatives. International Journal of Event Management Research.,. Vol. 8, No, 1. 2014 pp 19-34.

Tarlow, P., (2014) Tourism Security-Strategies for Effectively Managing Travel Risk and Safety. .Elsevier. pp. 23-43

Tarlow P., (2014)., Tourism Orientated Policing and the Tourism Industry. International Journal of Event Management., Vol 8. No 1, 2014 Special Edition Risk Management.pp1-18

Tourism Victoria (2015) Crisis Management Guide. www.tourism.vic.gov.au/business-toolssupport/crisis-management-guide. accessed 28/1/2016

Trading Economics.(2016) http://www.tradingeconomics.com/turkey/tourist-arrivals Accessed 30 June 2016.

Weaver, D., Lawton, L., (2014) Tourism Management Fifth Edition., John Wiley \& Sons. Milton QLD. Australia. pp 84-87

World Travel and Tourism Council. www.wttc.org accessed 28/11/2016 